\title{
Distillers dried by-products from barley as protein source for ruminants
}

\author{
MATTI NÄSI \\ University of Helsinki, Department of Animal Husbandry, \\ 00710 HELSINKI, Finland
}

\begin{abstract}
The nutritive value of barley-derived distillers dried grains (BDDG) and distillers dried grains with solubles (BDDGS) was assessed in digestibility and in sacco rumen degradability experiments. The crude protein contents of BDDG and BDDGS were $26.4 \%$ and $29.9 \%$, and the crude fibre contents $19.9 \%$ and $17.4 \%$ in DM, respectively. The ADF and NDF contents averaged $33 \%$ and $67 \%$ and the lignin $7.6 \%$ of DM. The digestibilities of the nutrients were measured with four rams in both trials and the distillers by-products were given at two levels, $33 \%$ ad $66 \%$, in hay-based rations. The digestibilities in BDDG and BDDGS were, respectively, $43.1 \%$ and $47.7 \%$ for organic matter, $64.5 \%$ and $66.5 \%$ for crude protein, and $86.7 \%$ and $87.9 \%$ for ether extract. Due to the low digestibilities, the energy values of the two products were low, $0.58 \mathrm{FU} / \mathrm{kg} \mathrm{DM}$ and $8.0 \mathrm{MJ} / \mathrm{kg}$ for both, and DCP/FU $295 \mathrm{~g}$ for BDDG and $347 \mathrm{~g}$ for BDDGS. The rumen degradability of the crude protein of BDDG and BDDGS was found to be low and significantly lower than the degradability of wheat distillery by-products $(\mathrm{P}<0.05)$. Fine grinding gave more rapid degradability. Due to the low total digestibility and reduced lysine content, BDDG and BDDGS may have limited protein availability when given as supplements.
\end{abstract}

\section{Introduction}

The desire to increase the domestic protein supply to meet the demand for cattle feeding has stimulated interest in utilizing various agro-industrial by-products. Distillers feeds consist of fermentation residues from the distilling industry. During yeast fermentation of grain nearly all starch is removed, so that the protein and other components become more cocentrated. Distillers dried grains (DDG) and brewers spent grains
(BSG) are major by-products from commercial ethanol distilling and the brewing industry. At present little information is available concerning the characteristics and nutritional value of barley distillers by-products. However, barley is the main raw material in the integrated starch-ethanol production planned to start in 1987 in Finland, with an expected of 61700 tn DM feedstuff annual yield (LeHMUSSAARI 1984). Distillers grains from barley contain the fibrous barley hulls, which makes barley-derived products very 
different from those from wheat or other grains and also increases the residue yield (Kaufmann and Emeis 1965, Newman and Gras 1983).

The distillery by-products studied in the present experiments are quite different from the feedstuffs that will be obtained from the new process, but they should provide information on the nutritional value of ethanol fermentation residues from barley as protein supplements for ruminants.

\section{Materials and methods}

Barley-derived distillers dried grains (BDDG) and distillers dried grains with solubles (BDDGS) were obtained from $\mathrm{OY} \mathrm{Al-}$ ko AB's Koskenkorva factory. From the whole barley stillage, the residues from the distillation process, the coarse grains were separated and dried to produce BDDG and the solubles were condensed by evaporating to produce BDDGS together with dried distillers grains. Drying was done in a drum dryer. Two digestibility and nitrogen balance trials were conducted, with four rams in each trial, to determine the nutritive value of barley distillers by-products. Each trial consisted of two 21-day periods. During the first period BDDG or BDDGS composed $33 \%$ of diet dry matter (DM) and hay $67 \%$; during the second period BDDG or BDDGS composed $67 \%$ of diet DM and hay $33 \%$. The ration was given at maintenance level, $50 \mathrm{~g}$ $\mathrm{DM} / \mathrm{kg} \mathrm{W}^{0.75}$. Finn sheep rams weighing on average $83 \mathrm{~kg}$ received $1400 \mathrm{~g}$ of the BDDG diet daily, and Texel rams weighing on average $44 \mathrm{~kg}$ received $875 \mathrm{~g}$ of the BDDGS diet daily. In addition mineral mixture was given daily and water was available ad libitum.

Each of the two periods consisted of a 14-d adjustment period followed by a 7-d collection period, when faeces and urine were recorded daily and subsampled for analysis. Samples of the experimental feeds were taken for every period.
The dry matter contents were determined by oven heating at $103{ }^{\circ} \mathrm{C}$ and samples for feed analysis were dried in a vacuum oven at $50{ }^{\circ} \mathrm{C}$. The feed analyses were made on the dried samples by standard methods. Acid detergent fibre (ADF), neutral detergent fibre (NDF) and lignin (ADL) were determined according to CoERING and VAN SOEST (1970). Crude lignin and water-soluble carbohydrates were determined as described by SALO (1965). Hay was analysed for in vitro digestibility according to TILLEY and TERRY (1963). In sacco rumen degradability of barley and wheat distillery by-products was determined in a nylon bag (porosity $40 \mu \mathrm{m}$ ) as described by SETÄLÄ (1983).

The digestibilities for the distillers byproducts were calculated by the regression technique from diet digestibilities, as the experimental rations composed different proportions of the individual feeds (SCHNEIDER and Flatt 1975). Effective protein degradability was calculated using a 0.04 dilution rate from the rumen according to the equation of KRISTENSEN et al. (1982).

\section{Results and discussion}

The chemical composition of the experimental feeds used in the digestibility trials are shown in Table 1. The barley distillers by-products had quite a high percentage of crude protein, $26-30 \%$, but very high contents of crude fibre, $17-20 \%$ of DM. The lignin content was high, too, $7-8 \%$. The starch has been removed by the fermentation process and the proportions of the other constituents of barley are two to three times as great as in the original material. Barley hulls make up about $10-12 \%$ of the grain and its chemical composition is comparable to straw (Salo and Kotilainen 1970), so that this fibrous material reduces the feed value of barley distillers grains. The chemical compositions of BDDG and BDDGS were similar. Wheat distillers grains had a higher crude protein content but a much lower 
Table 1. Chemical composition of barley dried distillers grain (BDDG), barley dried distillers grain with solubles (BDDGS) and hay used in digestibility experiments.

\begin{tabular}{lrrrr}
\hline & BDDG & BDDGS & $\begin{array}{c}\text { Hay, } \\
\text { experiment I }\end{array}$ & $\begin{array}{c}\text { Hay, } \\
\text { experiment II }\end{array}$ \\
\hline Dry matter & 94.8 & 94.5 & 85.0 & 84.1 \\
Ash & 4.1 & 4.4 & 6.1 & 5.6 \\
Crude protein & 26.4 & 29.9 & 7.8 & 5.9 \\
True protein & 21.6 & 27.6 & 5.8 & 4.3 \\
Ether extract & 7.7 & 6.4 & 1.9 & 36.9 \\
Crude fibre & 19.9 & 17.4 & 38.3 & 50.2 \\
Nitrogen-free extract & 41.9 & 41.9 & 45.9 & \\
Acid detergent fibre & 33.0 & 33.8 & & \\
Neutral detergent fibre & 61.9 & 69.4 & & \\
Acid detergent lignin & 9.9 & 13.5 & & \\
Lignin & 7.4 & 7.9 & & \\
Water-soluble & 2.0 & 5.3 & & 66.6 \\
carbohydrates & & & & \\
In vitro digestibility & & & 64.9 & \\
Dry matter & & & 63.5 & \\
Organic matter & & & & \\
\hline
\end{tabular}

crude fibre content (Table 4). Moss and KEZAR (1982) reported $23 \%$ crude protein and $21 \%$ crude fibre for wet distillers grains from barley ethanol. The ADF and NDF of the present BDDG were a little higher than those found by Newman and Gras (1983). Water-soluble carbohydrates were low, which indicates that the fermentation was efficient.

Table 2 presents the digestibility values of the diets containing distillery by-products at two levels of the ration 33 and $67 \%$. The digestibilities for BDDG and BDDGS were calculated by the regression technique from the quantities of each feed consumed in each digestion trial and the digestion coefficients of the rations. This method eliminates the associative effects on digestibility of different feeds given together (SCHNEIDER and FLATT 1975).

The digestibilities of both BDDG and BDDGS were found to be low: for organic matter $43 \%$ and $48 \%$, respectively, and for

Table 2. Digestibility coefficients of the diets including dried barley distillers grain (BDDG) or dried barley distillers grain with solubles (BDDGS) at two levels, 33 and $67 \%$ diet of dry matter.

\begin{tabular}{|c|c|c|c|c|c|c|c|c|}
\hline & \multicolumn{2}{|c|}{$\begin{array}{c}33 \% \text { BDDG } \\
67 \% \text { hay }\end{array}$} & \multicolumn{2}{|c|}{$\begin{array}{c}67 \% \text { BDDG } \\
33 \% \text { hay }\end{array}$} & \multicolumn{2}{|c|}{$\begin{array}{c}33 \% \text { BDDGS } \\
67 \% \text { hay }\end{array}$} & \multicolumn{2}{|c|}{$\begin{array}{c}67 \% \text { BDDGS } \\
33 \% \text { hay }\end{array}$} \\
\hline & $\overline{\mathbf{x}}$ & s.d. & $\overline{\mathbf{x}}$ & s.d. & $\tilde{\mathbf{x}}$ & s.d. & $\overline{\mathbf{x}}$ & s.d. \\
\hline \multicolumn{9}{|l|}{ Digestibilities } \\
\hline Dry matter & 57.9 & 1.7 & 50.0 & 2.5 & 58.1 & 1.0 & 52.1 & 1.9 \\
\hline Organic matter & 58.8 & 1.6 & 50.9 & 2.4 & 59.7 & 1.2 & 53.9 & 1.9 \\
\hline Ash & 43.7 & 3.3 & 34.3 & 5.1 & 27.9 & 13.1 & 16.4 & 7.1 \\
\hline Crude protein & 67.9 & 0.8 & 65.3 & 3.1 & 58.2 & 1.1 & 63.8 & 1.9 \\
\hline Ether extract & 79.9 & 1.6 & 83.8 & 2.4 & 83.5 & 1.6 & 86.2 & 1.9 \\
\hline Crude fibre & 46.0 & 1.3 & 26.0 & 3.9 & 57.7 & 1.5 & 42.4 & 2.6 \\
\hline N.F.E. & 63.1 & 3.0 & 55.6 & 1.9 & 59.9 & 1.0 & 51.6 & 1.9 \\
\hline Nitrogen balance, $\mathrm{g} / \mathrm{d}$ & 1.8 & 1.0 & -6.1 & 3.4 & 2.9 & 0.4 & 4.8 & 1.1 \\
\hline Biological value & 44.6 & 3.9 & 13.0 & 11.3 & 60.8 & 7.5 & 48.0 & 3.9 \\
\hline
\end{tabular}


Table 3. Digestibility coefficients of barley distillers grain (BDDG) and barley distillers grain with solubles (BDDGS) calculated by regression and their feed values.

\begin{tabular}{|c|c|c|}
\hline & BDDG & BDDGS \\
\hline \multicolumn{3}{|l|}{ Digestibilities } \\
\hline Dry matter & 42.5 & 47.5 \\
\hline Organic matter & 43.1 & 47.7 \\
\hline Crude protein & 64.5 & 66.6 \\
\hline Ether extract & 86.7 & 87.9 \\
\hline Crude fibre & -12.2 & 10.6 \\
\hline N.F.E. & 47.8 & 41.5 \\
\hline \multicolumn{3}{|l|}{ Feed values } \\
\hline $\mathrm{FU} / \mathrm{kg} \mathrm{DM}$ & 0.576 & 0.578 \\
\hline $\mathrm{kg} / \mathrm{FU}$ & 1.74 & 1.73 \\
\hline DCP $\%$ of DM & 17.0 & 20.0 \\
\hline $\begin{array}{l}\mathrm{DCPg} / \mathrm{FU} \\
\text { van Es system }\end{array}$ & 295 & 347 \\
\hline $\mathrm{GE}, \mathrm{MJ} / \mathrm{kg} \mathrm{DM}$ & 20.47 & 20.33 \\
\hline $\mathrm{ME}, \mathrm{MJ} / \mathrm{kg} \mathrm{DM}$ & 8.16 & 8.15 \\
\hline $\mathrm{q}=\mathrm{ME} / \mathrm{GE}$ & 0.40 & 0.40 \\
\hline NEW, MJ/kg DM & 3.98 & 3.99 \\
\hline $\mathrm{NEL}, \mathrm{MJ} / \mathrm{kg} \mathrm{DM}$ & 4.45 & 4.45 \\
\hline $\mathrm{km}, \mathrm{f}$ & 0.49 & 0.49 \\
\hline$k_{1}$ & 0.56 & 0.56 \\
\hline $\mathrm{ME}, \mathrm{MJ} / \mathrm{kg} \mathrm{MAFF}$ & 8.01 & 8.02 \\
\hline $\mathrm{ME}, \mathrm{MJ} / \mathrm{kg} \mathrm{DM}$ Axelsson & 8.63 & 8.69 \\
\hline
\end{tabular}

crude protein $65 \%$ and $67 \%$. The values in this experiment were a little lower than the Canadian results for barley distillers byproducts, whose DM digestibility was $54.5 \%$ and whose crude protein value was $78.3 \%$ (Moss and KeZAR 1982). The values for wheat DDGS were $70-72 \%$ for organic matter and $78-80 \%$ for crude protein (SALo et al. 1982). The low digestibilities of
BDDG and BDDGS may be attributed to their fibrous hull contents and to the rapid rate of passage of small particles through the forestomachs (Poutiainen 1968).

Due to the low digestibilities, the energy values were low. The calculated net energy values were the same fot both products, 0.58 $\mathrm{FU} / \mathrm{kg} \mathrm{DM}$. In the net energy evaluation the value number 0.80 was used, which is given for distillery by-products in feed tables (SALo et al. 1982). The value is evidently overestimated for barley by-products, because the equation of V VN Es (1978) yielded only 0.53 for the metabolization of gross energy compared with 0.95 for barley. ETtAla and NĀsI (1983) performed feeding experiments with growing cattle to evaluate some agro-industrial by-products as feed and found that BDDGS had a low nutritive value when used as supplement in a high straw diet. When cattle given BDDGS $1.5 \mathrm{~kg}$ plus $1.5 \mathrm{~kg}$ barley were compared with cattle receiving $3.0 \mathrm{~kg}$ barley supplemented with NPN, the daily gains averaged $786 \mathrm{~g}$ and $904 \mathrm{~g}$, respectively. The dressing percentages were low for both treatments, 42.4 and $44.3 \%$. Thомаs (1982), however, found that the performances with BDDG were similar to those with soybean as protein supplement for cattle.

The nitrogen balances were positive in the rams on rations containing BDDGS and increased with greater inclusion. The Texel rams gained $1.8 \mathrm{~kg}$ on average during the experiment. The rams on rations containing BDDG had a slightly positive balance at the

Table 4. Chemical composition of different barley and wheat distillers products used in in sacco rumen degradability measurements.

\begin{tabular}{|c|c|c|c|c|c|c|}
\hline & \multicolumn{3}{|c|}{ Barley } & \multicolumn{3}{|c|}{ Wheat } \\
\hline & DDG & DDGS & $\begin{array}{c}\text { DDGS } \\
\text { fine }\end{array}$ & DDG & DDGS & $\begin{array}{c}\text { DDGS } \\
\text { fine }\end{array}$ \\
\hline Dry matter & 95.5 & 93.5 & 96.1 & 94.9 & 93.9 & 94.6 \\
\hline Ash & 3.9 & 4.4 & 7.2 & 7.8 & 4.9 & 6.9 \\
\hline Crude protein & 28.6 & 31.1 & 35.4 & 40.6 & 45.8 & 42.8 \\
\hline Ether extract & 5.0 & 5.0 & 5.3 & 5.4 & 5.1 & 5.1 \\
\hline Crude fibre & 17.4 & 16.1 & 11.2 & 9.9 & 10.8 & 10.1 \\
\hline N.F.E. & 45.1 & 43.3 & 40.8 & 36.4 & 33.4 & 35.0 \\
\hline
\end{tabular}


lower level but a negative balance at the higher level. The biological values were rather low for all the rations (Table 2). The protein values were fairly suitable, $295 \mathrm{~g}$ DCP/FU for BDDG and $347 \mathrm{~g} \mathrm{DCP/FU} \mathrm{for}$ BDDGS. Wheat DDGS has a FU value of $0.72 / \mathrm{kg} \mathrm{DM}$ and $336 \mathrm{~g} \mathrm{DCP} / \mathrm{FU}$ (SALO et al. 1982).

The barley distillers grains had low in sacco rumen degradability (Table 5). The high temperatures during boiling and drying reduce the degradation of crude protein. Grain protein generally has rapid and high degradation in the rumen (SAlo et al. 1982). Low degradability is suitable for ruminant protein supplement. BDDG and BDDGS had reduced contents of lysine, 3.2 and $1.7 \mathrm{~g} / 16 \mathrm{~g} \mathrm{~N}$ and, the availability of lysine was very low (NÄsı 1984). The protein in barley distillers by-products, although resistant to microbial degradation in the rumen, has limited value as a protein supplement because of its low digestibility and availability. WDDGS also had low degradability. This may result from the treatments during processing, especially condensing of solubles during drying. Fine grinding (average particle size $0.5 \mathrm{~mm}$ ) was also compared with normal grinding (average particle size $1.0 \mathrm{~mm}$ ). Fine grinding gave products with a lower fibre content but higher protein content, indicating that partial fractionation had occurred (Table 4). Fine grinding led to rapid and almost full degradation. This is partly due to the very small particle size. The solubility of the DM of these products in water was $64.6 \%$ for fine WDDGS and $42.7 \%$ for fine BDDGS. The corresponding values for WDDG and WDDGS were $34.8 \%$ and $30.0 \%$, and for BDDG $21.7 \%$ and BDDGS $22.7 \%$, respectively. In the feed tables of SALO et al. (1982) the degradability of the crude protein of DDGS is given as $60 \%$ in two hours and the total degradability as $65 \%$. WALLER et al. (1980) have shown that, due to its low rumen degradability, corn DDGS fed together with urea is comparable to soybean meal as a protein supplement for steers. Corn

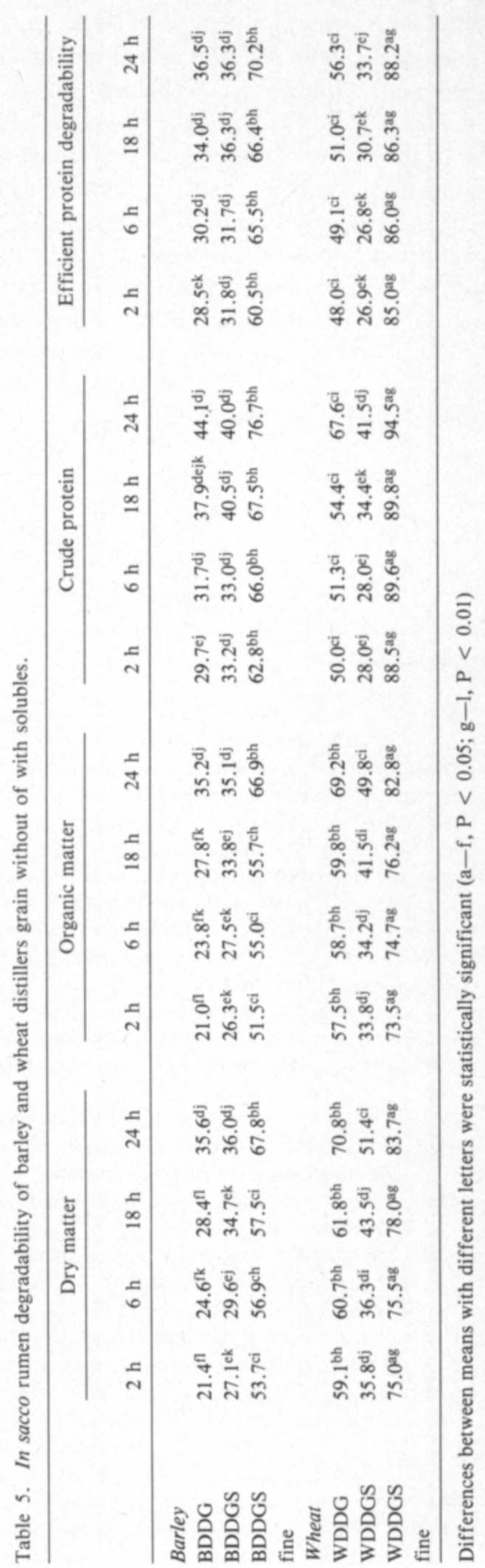


DDGS has also been shown to contain substances that stimulate the rumen, increasing protein utilization and cellulose digestion (CHEN et al. 1977).

In the present experiments, performed to evaluate the nutritive value of barley distillers by-products, both BDDG and BDDGS were found to have a low energy value and limited protein availability. This is in good agreement with the results of an earlier feeding experiment with growing cattle (ETTALA and NÄSI 1983) and of a balance trial with pigs (NäSı 1984). Many suitable feedstuffs can be expected from the planned integrated ethanol-starch production, in which the barley raw material will first be dehulled and then divided into starch, protein and fibres. Only starch is used in ethanol fermentation. After distillation, condensed solubles are obtained. The different fractions can be combined in many different ways to yield suitable products for feeding purposes. Wet preservation of distillery by-products also deserves study as a means of eliminating protein denaturation during drying.

\section{References}

Chen, M.C., Beeson, W.M., Perry, T.W. \& Mohler, M.T. 1977. Effects of varying levels of processed distillers solubles and distillers grains with solubles on nitrogen and energy metabolism of beef steers. J. Anim. Sci. 44: 859-866.

Coering, H.K. \& Van Soest, P.J. 1970. Forage fiber analyses: apparatus, reagents, procedures and some applications. U.S. Dep. Agric. Handb. No 379: 8-9.

Es, A.J.H.VAN. 1978. Feed evaluation for ruminants. 1. The systems in use from May 1977 onwards in the Netherlands. Livest. Prod. Sci. 5: 331-345.

EttalA, E \& NĀSI, M. 1983. Unpublished results.

KaufmanN, W. \& Emeis, C.C. 1965. Nebenprodukte der Gärungsgewerbe. Handbuch der Futtermittel 3: 88102.

Kristensen, E.S., Møller, P.D. \& Hvelplund, T. 1982. Estimation of effective protein degradability in the rumen of cows using the nylon bag technique combined with the outflow rate. Acta Agric. Scand. 32: 123-127.

LehmUSSAARI, A. 1984. Integroitu tuotanto. Etanoli tärkkelys - tärkkelyssokeri. Esitelmä. Oy ALKO Ab. Process Engin. Div. Rajamäki. 5 p.

Moss, B.R. \& Kezar, W. 1982. Digestibility of wet distillers grain from barley ethanol as easured with sheep. Rep. Dep. of Agric. From the MSU biofuels research. Montana University. Mimeogr. p. 42-45.

Newman, C.W. \& Gras, P.W. 1983. Utilization of barley distillers dried grains in swine growing diets. Proc. West. Sect. Am. Soc. Anim. Sci. 34: 138-141.

NÄSI, M. 1984. Evaluation of barley distillers dried grains with solubles, and condensed distillers solubles in the diet of growing pigs. J. Agric. Sci. Finl. 56: 221-226.

Poutiainen, E. 1968. Factors influencing the flow of fluid, saliva and some cations through the reticuloomasal orifice of the cow. Ann. Agric. Fenn. 7: $1-66$.

SALo, M.-L. 1965. Determination of carbohydrate fractions in animal foods and faeces. Acta Agr. Fenn. 105: 1-102.

-, \& Kotilainen, K. 1970. On the carbohydrate composition and nutritive value of some cereals. J. Scient. Agric. Soc. Finl. 42: 21-29.

-, TuORI, M. \& KIISKINEN, T. 1982. Rehutaulukot ja ruokintanormit. 70 p. Helsinki.

SetĀlÄ, J. 1983. The nylon bag technique in the determination of ruminal feed protein degradation. J. Scient. Agric. Soc. Finl. 55: 1-78.

SChneider, B.H. \& Flatt, P.W. 1975. The evaluation of feeds through digestibility evaluation. Univ. Georgia Press. Athens. 423 p.

Tilley, J.M.A. \& Terry, R.A. 1963. A two-stage technique for in vitro digestion of forage crops. $\mathrm{J}$. Br. Grassl. Soc. 18: 104-111.

Tномаs, O.O. 1982. Replacement value of dry barley stillage for soybean oil meal. Rep. Dep. of Agric. From the MSU Biofuels research. Montana State University. Mimeogr.

W Aller, J., Kloppenstein, T., Poos, M. 1980. Distillers feeds as protein sources for growing ruminants. J. Anim. Sci. 51: 1154-1167.

Ms received August 17, 1984 


\section{SELOSTUS}

\section{Ohrarankkirehujen arvo märehtijäin valkuaisrehuna}

\section{Matti Näsi}

Helsingin yliopisto, Kotieläintieteen laitos, 00710 Helsinki 71

Tutkimuksessa selvitettiin ohrasta etanolin valmistuksen sivutuotteina syntyvien rankkirehujen: rankkijyvien (BDDG) sekä rankkijyvien ja rankkiuutteen seoksen (BDDGS) koostumusta, sulavuutta ja pötsihajoavuutta. Rankkirehujen valkuaispitoisuus oli $26-30 \%$ ja raakakuitupitoisuus $17-20 \%$. Sulavuusmääritykset tehtiin păsseillă kahdessa kokeessa, joissa rankkirehuja syötettiin 33 tai $67 \%$ heinăăn perustuvan dieetin kuiva-aineesta. Rankkijyvien ja rankkiseoksen sulavuuksiksi saatiin orgaaniselle aineelle 43 ja $48 \%$, raakavalkuaiselle 65 ja $67 \%$ sekä raakarasvalle 87 ja $88 \%$. Rehuyksikköarvoksi saatiin $0.58 / \mathrm{kg}$ ka., muuntokelpoisen ener- gian măărăksi $8.0 \mathrm{MJ} / \mathrm{kg}$ molemmille rankkituotteille ja sulavaa raakavalkuaista oli 295 ja $347 \mathrm{~g} /$ ry.

Rankkirehujen pötsihajoavuus oli hidasta sekä vähăistă ja ohrarankkirehujen hajoavuus oli merkitsevăsti vehnärankkituotteita văhäisempaaả. Alhaisesta sulavuudesta ja kăyttőkelpoisen lysiinin văhăisyydestă johtuen ohrarankkirehujen valkuaisarvo on melko heikko văhäisestă pötsihajoavuudesta huolimatta.

Integroidusta etanoli-tärkkelystuotannosta saadaan ohrasta käyttőkelpoisia rehufraktioita, kun eri jakeita voidaan yhdistää halutulla tavalla ja kuumennuskäsittelyjä voidaan tarkemmin kontrolloida. 